\title{
Managing visitors' dining and retail experiences in South African national parks
}

\author{
M. Kruger, M. Saayman* and E. Slabbert \\ TREES (Tourism Research in Economic Environs and Society), North-West University, Potchefstroom, South Africa \\ *To whom all correspondence should be addressed \\ Melville.Saayman@nwu.ac.za
}

\begin{abstract}
In the light of the issue of declining government funding of South African National Parks (SANParks), as well as the negative influence of the poor service levels in shops, restaurants and eating facilities in these parks on visitor spending, SANParks needs to improve the retail and dining experiences at these facilities. This research attempts to provide guidelines for SANParks management in addressing these issues, by determining visitors' retail and dining preferences and the relationship between these constructs. Quantitative research was conducted in 2011 using a web-based survey on the SANParks' official website for two months ( $1^{\text {st }}$ October $-30^{\text {th }}$ November). This method resulted in obtaining 5464 usable responses for the study. Factor analyses identified three relevant dining experience factors: Quality, Variety and value and Nature ambience and four retail experience factors: Goods and services, Pricing (consisting of two separate constructs: Expensive shops and Pay more inside Park) and Quality. To the best of the authors' knowledge, this was the first time that research was conducted with regard to addressing visitors' retail and dining preferences at any South African national park, thereby contributing significantly to literature regarding visitor experiences in a nature-based context.
\end{abstract}

\section{Introduction}

One of South Africa's most important role players in wildlife based tourism at present is South African National Parks (SANParks) which currently manages 21 national parks, each representing a unique biological diversity of biomes, plants and animal species. National parks have three distinct purposes: the conservation of a representative sample of the biodiversity of the country; providing a recreational outlet where the wonders of the park may be experienced and enjoyed; and lastly, maintaining a relationship of community upliftment and capacity building among the people living in and around the parks (Saayman \& Saayman, 2008). These nature-based destinations are, furthermore, a major ecotourism attraction for local and foreign tourists, with 4.7 million tourists during the 2011/12 season contributing $80 \%$ of SANParks' revenue (Mabunda \& Wilson, 2009; SANParks, 2012a, b,c). However, one of the current challenges being faced by many conservation organisations including national parks is the reduction in government funding. Consequently, alternative sources of funding are required in order to grow and fulfill their mandate (Child, 2009; Eagles, 2007; Emerton, Bishop, Thomas, 2006; Mabunda, 2004; Mabunda \& Wilson, 2009; Varghese, 2008; Wyman et al., 2011; Saporiti, 2006).

SANParks therefore devised the Commercialisation Strategy (SANParks, 2011a,b:85), that aims to reduce the cost of delivery, improve service levels by focusing on core business and utilise private capital and skills in addition to expanding the range of tourism products as well as generating additional revenue for the funding of conservation (Varghese, 2008:71). This strategy includes the introduction of concessions to operate certain lodging facilities, restaurants and shops in order for SANParks to concentrate on conservation and biodiversity management. This has been a success with the exception of park shops and restaurants that have yielded a high level of negative feedback (SANParks Annual Report 2011/2012). For both the retail shopping and the dining experience, there has been a decrease in recorded performance levels from 2010/2011 to $2011 / 2012$. Shopping decreased from $69.7 \%$ in $2010 / 2011$ to $68.8 \%$ in $2011 / 2012$ and dining from $65.5 \%$ in 2010/2011 to $64 \%$ in 2011/2012. SANParks Annual Report 2011/2012 (2012a:31) further indicates that the performance of the restaurant operations remained the weakest of all the indicators measured and requires contract variation management. A model that will focus on standardisation of both product and service through a franchised brand is being considered as an alternative to the current concession contract (2012a:31). In this regard, the question remains: what are the consumers' needs? Visitors are especially displeased with the level of service as well as the limited and expensive options on the current menus and some even go as far to describe the food in some of the restaurants as "unappetizing" (Kruger, Scholtz \& Saayman, 2012). Park visitors desire more variety in terms of product and options, variable pricing, better presentation and greater availability of restaurants (SANParks Annual Report 2011/2012). In a media statement, Giju Varghese, SANParks Senior Manager: Business Development, pointed out that despite the fact that around 70 percent of all visitors to these parks are South African residents, the majority of the business in the restaurants comes from foreign guests and tour operators (Wray, n.d.). SANParks would therefore like to see an increase in both local and foreign tourists in the park 
restaurants, acknowledging that currently the "prices are very high", and that this may have driven many visitors (both international and locals) away (Wray, n.d.).

Feedback concerning the park shops is also critical of the product offerings. Not all national parks have a park shop, while those that do, offer visitors a restricted retail experience with limited and expensive options in terms of fresh produce, provisions and souvenirs etcetera (Kruger et al., 2012). SANParks Annual Report 2011/2012 (2012:31) indicates that, although factors such as cleanliness, customer service and availability are satisfactory to park visitors, aspects such as price, product options and quality of products need to be reviewed in existing shops in the parks. Kruger et al. (2012) further indicate that the majority of visitors to South African national parks prefer self-catering accommodation and that this could be an additional reason for the low numbers of visitors to park restaurants. These visitors still have to buy some form of supplies, especially in terms of fresh produce, at the particular park shop. However, the negative reputation of park shops encourages visitors to purchase most of their provisions outside the park, resulting in lower visitor spend inside the park. Mabunda (2004:86) confirms that due to bad service rendered by the parks' restaurants and take-away outlets, budget traveller groups and luxury market groups prefer to stay outside the park for better food and comfort, only entering as day visitors, resulting in serious economic implications. Gäl et al. (2007:32) assert that "it is for these reasons that tourists visiting developing countries prefer fast-food (franchised) restaurants as well as franchised shops to traditional restaurants and shops", as franchised establishments provide consistency in their offerings and are well-known.

In the context of this study, "retail experience" refers to the aspects that influence visitors' experiences at the park shops, such as fast moving goods, benefits for Wild Card holders, branded items, fresh products and pricing. "Dining preferences" refer to the factors that influence visitors' experience at park restaurants and take away facilities, such as value for money, variety of product options, quality of meals, and service standards. A "memorable" retail and dining experience refers to a satisfactory and impressive one that will encourage visitors repeatedly to make use of these facilities and positively recommend them to others. Findings indicate that hospitality expense versus experience makes up $73 \%$ of the total trip experience to SANParks, confirming the importance of this aspect (Saayman \& Scholtz, 2012). Since SANParks offer no alternatives with respect to the park shops, restaurants and take-away facilities, park management should focus on improving the current retail and dining experience, based on what visitors regard as important for a memorable one. All park visitors require food, either groceries or prepared food from restaurants or take-away facilities. The purchase of food is therefore a major expenditure for visitors and the park has the potential to earn a substantial income from this source (Eagles, McCool \& Haynes, 2002:122). Empirical studies about travel dining behaviour of tourists are however very limited in number, and there is a notable knowledge gap with regard to attributes that affect how tourists evaluate their travel retail and dining experiences (Chang, Kivela \& Mak, 2011; Lloyd, Yip \& Luk, 2011; SANParks, 2012; Van Westering, 1999). According to Yüksel and Yüksel (2002:64), "tourists' evaluation of retail and dining experiences appears to be a complex process in which several factors are processed". The latter could be especially true in a nature-based context.

The purpose of this research is therefore threefold: firstly to determine the factors that influence visitors' retail and dining experiences in SANParks; secondly, to determine whether there is a relationship between these experiences and thirdly to determine whether the use of park restaurants/shops influences such experiences. This information could greatly assist SANParks and other naturebased attractions to improve their current service levels as well as retail and dining experiences, thereby reducing negative feedback and improving the image and reputation of the current facilities. This may result in experiences that due to their quality and memorability encourage higher spending by tourists. An increased income from the tourist revenue source is vital for the future sustainability of these protected areas in South Africa.

\section{Literature review}

All travellers have to eat when they travel, and thus engage in some form of retail and travel dining (Chang et al., 2011). Eating is a form of tourist activity that gratifies all five senses (Chang et al., 2011; Kivela \& Crotts, 2006; Loyd et $a l ., 2011)$ and spending on food may constitute up to onethird of the total tourist expenditure (Boyne, Williams \& Hall, 2002; Hall \& Sharples, 2003; Telfer \& Wall, 2000), thus comprising a significant proportion of tourism revenue (Mak, Lumbers \& Eves, 2012). Food in an assortment of forms and enhancements is therefore an important tourist attraction and is central to the visitor experience ( $\mathrm{Ab}$ Karim \& Geng-Qing Chi, 2010; Henderson, 2009). The centrality of dining in the travel experience is manifested, not merely in its basic function as sustenance, but also in its various forms of benefits that augment the overall travel experience (Chang et al., 2011:307). Travel dining especially is, per se, a "pleasurable, sensory experience" that fulfills an essential part of a holiday experience (Kivela \& Crotts, 2009). It offers a "pleasure factor" that "pulls" tourists to a destination (Kivela \& Crotts, 2006, 2009). Tourists therefore expect top service and food quality and there is a strong demand for a wide variety of dining venues and menu options, with an increasing emphasis on regional specialties and fresh ingredients (Brumback, 1999). Creating and ensuring memorable travel retail and dining experiences is, however, a complex process. As shown in Figure 1, three aspects that influence the experience need to be considered: the tourist, the dining facilities at the destination and the factors that influence these experiences at the destination (Mak et al., 2012). The influence of each of these aspects is discussed briefly in the next section. 


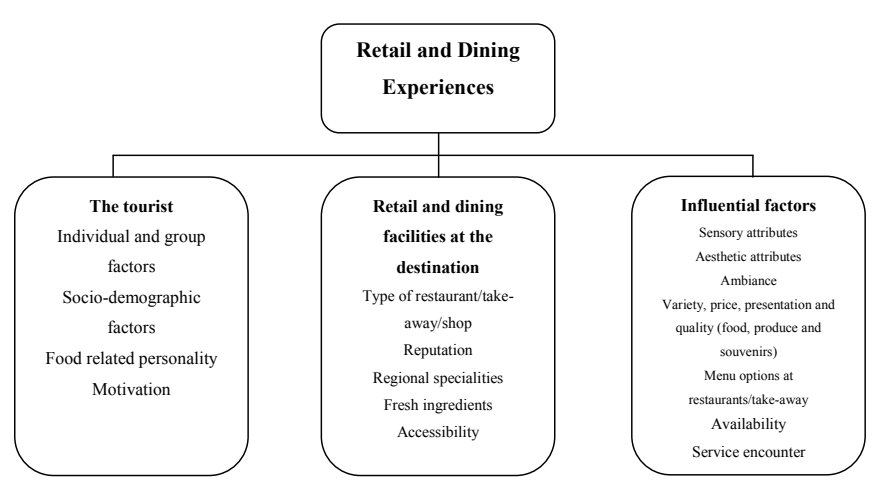

Figure 1: Aspects affecting the travel retail and dining experience

Source: Adapted from Mak et al. (2012:930)

According to Yüksel and Yüksel (2002) and Long (2004), the first aspect concerns the issue that different tourists may have differing perceptions about what contributes to a satisfactory travel dining experience. For example, one tourist may be attracted to a gastronomic experience in his/her desire for high quality food, while another may be interested in the non-food aspects such as location and decoration (Correia, Moital, Ferreira da Costa \& Peres, 2008). Tourists' individual group factors (Bowie \& Buttle, 2011; Gäl et al., 2007), socio-demographic factors (Kumar, 2010; Mak et al., 2012), food related personality (Chang, Kivela \& Mak, 2010; Kim, Eves \& Scarles, 2009; Mak et al., 2012:932; Tse \& Crotts, 2005) and motivation may therefore influence (Kim et al., 2009; Mak et al., 2012) their travel dining experience.

Regarding the second aspect, Henderson (2009) indicates that the retail and dining facilities (shops and restaurant/take-away facilities) at a destination are a core tourism product; consequently, food and drink outlets may be designed principally for tourists or depend heavily on them (as in the case of SANParks). Restaurants and takeaway facilities are generally assumed to be in the business of selling food only (Yüksel \& Yüksel, 2002). These dining facilities are, however, primarily retailers of "foodservice experiences" (Yüksel \& Yüksel, 2002). Regarding park shops, these facilities are not only seen as retail providers, but also as providing additional spending opportunities to tourists in terms of purchasing quality and affordable books, clothing and souvenirs. Hall and Mitchell (2001) found that retail and dining facilities were seen as adding to a destination's image through their reputation, through that destination's culture, by adding variety, being unique as well as through the associated relaxing and indulgent lifestyle. It is recognised that the kind of products, foods and drinks on offer for tourists can have major implications for the economic, cultural and environmental sustainability of tourism destinations, with researchers arguing that a focus on locally sourced products may result in benefits for both host and guest (Boniface, 2003; Clark \& Chabrel, 2007; Hartman, Meyer \& Scribner, 2009; Hurst, Niehm \& Littrell, 2009; Ilbery, Kneafsey, Bowler, Clark, 2003; Torres, 2002; Rogerson, 2011; Woodland \& Acott, 2007; Sims, 2009).
Regarding the third aspect (see Figure 1), not much research has focused on consumers' retail and dining satisfaction and experiences, especially at nature based destinations/ products; nonetheless, many studies have focused on assessing the food experience satisfaction at dining facilities in general. These studies have focused on different types of restaurants such as fast food (Brady \& Robertson, 2001) and themed restaurants (Weiss, Feinstein \& Dalbor, 2004), and on different contexts, including hospitals (O'Hara et al., 1997) and schools (Meyer \& Conklin, 1998). Recognizing that food experiences are not similar for all individuals, some studies focused on different segments, such as the elderly (Meyer \& Conklin, 1998). In earlier studies, Spark, Wildman and Bowen (2000), Neild, Kozak and LeGrys (2000) as well as Hjalanger and Corigliano (2000) found that dining facilities such as restaurants were perceived as important to tourists' overall satisfaction with a destination, and as a significant dimension of the tourism product. However, besides serving excellent food, good service, the location of the restaurant, its decor and intangible aspects such as the ambience and atmosphere were reported to be important factors essential to enhance the dining experience. Yüksel and Yüksel (2002) reported that service quality followed by product quality, hygiene, menu diversity, pricevalue and convenience had the most significant effect on dining satisfaction. Sparks, Bowen and Klag (2003) went further and identified the following restaurant characteristics in terms of consumers' choice: display of a menu, attractive decor or atmosphere, wide variety of food on the menu, the restaurant looking busy and local food on the menu.

In more recent studies, Ryu and Jang (2007) identified five factors contributing to the dining experience in a restaurant context, namely aesthetics, lighting, atmosphere, layout and table accessories. According to Gül et al. (2007:38) factors such as restaurant type, food type, atmosphere, and other restaurant facilities were significant. Correia et al. (2008) measured the satisfaction of gastronomic tourists in Portugal and identified three factors: gastronomy (local courses, staff presentation, originality and exotic nature and food presentation), price and quality (price of drinks, price of food and quality and price), and atmosphere (ethnic decoration, decoration, modern music, lighting and entertainment). According to Kim et al. (2009:428) key elements with regard to physical environment included cleanliness of local restaurants or restaurants, together with a traditional appearance. In their study of Chinese tourists' evaluation of their travel dining experiences, Chang et al. (2011) identified six attributes affecting the evaluation of travel dining experiences: tourists' own food culture (flavour and cooking method), the contextual factor of the dining experience (authenticity and experiential factor), variety and diversity of food (variety of dishes and diversity of meal arrangement), perception of the destination (gastronomic identity and expected service level), service encounter (pleasure of being served and service speed) and tour guides' performance (interpretation and facilitation). Ryu and Han (2011) found that aspects such as facility aesthetics, lighting, layout and service staff significantly influenced experiences in restaurants while $\mathrm{Su}$ (2011) 
emphasised the influence of service innovation on satisfied restaurant experiences.

The aforementioned factors highlight the increasing importance of the travel retail and dining experiences to the overall travel experience. These further stress the important contribution that travel retail and dining experiences make to the tourist destinations' attractiveness and the influence the former exert on travellers' choice when selecting a holiday destination (Sparks, Bowen \& Klag, 2003; Tsai \& $\mathrm{Lu}, 2012)$. Although in a national park, these facilities are secondary to wildlife viewing, yet are still important from an economic and experience point of view. Understanding what tourists regard as important aspects for a memorable retail and dining experience at South African national parks will enable SANParks to improve the current level of services at the park restaurants and take-away facilities based on their visitors' needs. Additionally, this will reduce potential negative feedback concerning shops and restaurants and will increase visitor spending in the parks.

\section{Method of research}

As this was a quantitative study, a structured questionnaire was used to collect the data. This section describes the questionnaire, sampling method and survey as well as the statistical analysis.

\section{The questionnaire}

The questionnaire used in the survey consisted of four sections. Section 1 captured socio-demographic and behavioural information (gender, year of birth, home language, marital status, province of residence, highest level of education, gross annual income, accommodation preference when staying in a national park, purchasing behaviour, use of Park restaurants and opinions regarding cultural products and bed and breakfast accommodation in national parks). Section 2 captured respondents' opinions on the acceptability of introducing branded restaurants and take away outlets into national parks. Respondents were asked to give reasons for total disagreement with introducing branded food service outlets and were asked which brands they felt were not acceptable in national parks. Section 3 captured respondents' perspectives regarding the importance of aspects related to dining in national parks. Perspectives such as value for money, variety of product options, quality of meals and service standards were identified and rated on a five-point Likert scale of importance where $5=$ not important at all; $4=$ slightly important; $3=$ important; $2=$ very important and $1=$ extremely important. Section 4 captured respondents' level of agreement with regard to comments related to the offerings of shops in national parks. A five-point Likert scale was used to rate the level of agreement for each statement related to the use of shops in the park where $5=$ totally disagree; $4=$ disagree; $3=$ neutral; 2 = agree and $1=$ totally agree.

\section{Sampling method and survey}

Quantitative research was conducted in 2011 by means of a web-based survey. The survey was constructed using SurveyMonkey and posted on the SANParks' official website for a period of two months $\left(1^{\text {st }}\right.$ October $-30^{\text {th }}$ November). Thus, any person with an interest in national parks could participate in this study. Once the questionnaire was completed, it was automatically referred to a database and converted to an Excel spreadsheet. This method resulted in 5464 usable responses for the study. Therefore, nonprobability sampling, that is, convenience sampling, was implemented.

\section{Statistical analysis}

Data was analysed using the Statistical Programme for Social Sciences (SPSS 19.0). The analysis was performed in four stages: a general profile of the respondents, two factor analyses to determine the factors underlying the dining experience and the retail experience in the Parks and an analysis demonstrating the relationship between selected demographic characteristics and the retail and dining experience factors.

Descriptive statistics focused firstly on the demographic profile of the respondents, where frequencies were used to analyse the data. Two principal axis factor analyses, using an Oblimin rotation with Kaiser normalisation, were performed on the 9 dining experience items and 11 retail experience items, to explain the variance-covariance structure of a set of variables through a few linear combinations of these variables. The Kaiser-Meyer-Olkin measure of sampling adequacy was used to determine whether the covariance matrix was suitable for factor analysis. Kaiser's criteria for the extraction of all factors with eigenvalues larger than one were used because they were considered to explain a significant amount of variation in the data. All items with a factor loading greater than 0.3 were considered as contributing to a factor, and all items with loadings less than 0.4 as not correlating significantly with this factor (Steyn, 2000). Any item that cross-loaded on two factors, with factor loadings both greater than 0.4 , was categorised into the factor where interpretability was best. A reliability coefficient (Cronbach's alpha) was computed for each factor to estimate its internal consistency. All factors with a reliability coefficient above 0.6 were considered as acceptable in this study. The average inter-item correlations were also computed as another measure of reliability these, according to Clark and Watson (1995), should lie between 0.15 and 0.55 . Correlation analysis and Spearman's Rank Order Correlation (rho) were used to explore the interrelationship between the retail and dining factors. According to Pallant (2010:134), a correlation of 0 indicates no relationship, whereas a correlation of 1.0 indicates a perfect positive correlation and a value of -1.0 indicates a perfect negative correlation. Cohen (1988:79-81) suggests the following guidelines to interpret the values between 0 and 1: small effect: $r=0.1$; medium effect: $r=0.3$; and a large effect: $r=0.5$. One-Way-Analysis of Variance (ANOVAs) 
were conducted to determine the relationships between the use of park restaurants and shops and respondents' dining and retail experiences in the South African national parks.

\section{Research results}

The results are presented in three sections - the demographic characteristics of respondents participating in the survey, the results of the factor analyses (factors influencing the dining experience and the factors influencing the retail experience) (purpose 1) and lastly the results of the correlation analysis (purpose 2) with an ANOVA (purpose 3) to show the relationship between park shop as well as restaurant usage and the dining and retail experiences.

\section{Demographic profile of respondents}

According to Table 1, more males participated in the study than females $(60 \%)$. The respondents were mostly between 41 and 60 years of age (54\%), married $(80 \%)$, mainly from Gauteng Province (42\%) and speaking either English (48\%) or Afrikaans (43\%). These participants had obtained either a diploma $(27 \%)$ or degree $(21 \%)$ and were earning more than R552 001 annually. This profile correlates with the visitor research conducted in South African national parks over the last 5 years (Kruger et al., 2012).

Table 1: Demographic profile of respondents

\begin{tabular}{l|l}
\hline VARIABLE & CATEGORY \\
\hline Gender & Male (60\%); Female (40\%) \\
\hline Age & $\begin{array}{l}41-50 \mathrm{yrs}(25 \%) ; 51-60 \mathrm{yrs}(29 \%) ; 61 \\
-70 \text { yrs. (22\%) }\end{array}$ \\
\hline Home language & $\begin{array}{l}\text { English (48\%); Afrikaans (43\%); Other } \\
\text { languages (9\%) }\end{array}$ \\
\hline Marital status & Married (80\%) \\
\hline Province of residence & $\begin{array}{l}\text { Gauteng (42\%); Western Cape (18\%); } \\
\text { Outside South Africa's borders (12\%) }\end{array}$ \\
\hline $\begin{array}{l}\text { Highest level of } \\
\text { education }\end{array}$ & $\begin{array}{l}\text { Diploma (27\%); Degree (21\%); Post- } \\
\text { graduate degrees (30\%) }\end{array}$ \\
\hline Gross annual income & $\begin{array}{l}\text { More than R552 001 (21\%); I would not } \\
\text { like to disclose my income (22\%) }\end{array}$ \\
\hline
\end{tabular}

Results of the factor analyses: Analysing the dining and retail experiences of visitors to South African national parks

This section focuses on exploring the perceived importance of factors related to dining and retail operations in SANParks (purpose 1 as stated in the introduction).

\section{Dining experience factors}

To examine the factors influencing dining at park restaurants, a principal axis factor analysis with oblique rotation (direct oblimin) was undertaken. One of the constructs of dining, namely, "to experience nature while dining", was taken out of the factor analysis due to poor correlation with other aspects and is treated as a separate item. This aspect was labelled Nature ambience. The mean for this item was 1.81. As shown in Table 2, the remaining seven restaurant aspects yielded two factors, namely, Quality and Variety and value, both with eigenvalues greater than 1.0; these factors explained $58 \%$ of the variance. All had factor loadings over 0.4, and the sample size was 5265. Reliability (Cronbach's $\alpha$ ) was computed to verify the internal consistency of aspects with each factor. Both factors with a Cronbach alpha were 0.701 and were deemed acceptable for the purpose of this study. Bartlett's test of sphericity was significant $(\mathrm{p}<0.001)$, and the Kaiser-MeyerOlkin measure of sampling adequacy (KMO) was 0.777 , which was acceptable. Factor scores were calculated as the average of all items contributing to a specific factor in order to interpret them on the original five-point Likert scale of measurement where $5=$ not important at all; $4=$ slightly important; 3 = important; 2 = very important and $1=$ extremely important. Quality (Factor 1) included factors such as service efficiency and quality of meals. Factor 2, Variety and value, included factors such as different pricing options, product options, value for money, pricing affordability and menu variety. Quality (1.38) yielded a significantly higher mean than Variety and value (2.19), indicating that satisfaction with park restaurants is more important than variety and value of offerings.

\section{Table 2: Results of the factor analysis for restaurant} factors

\begin{tabular}{l|c|c}
\hline \multirow{1}{*}{ Dining factors } & \multicolumn{2}{c}{ Factor loadings } \\
\cline { 2 - 3 } Factor 1: Quality & $\mathbf{2}$ & \\
\hline Quality of meals & 0.830 & \\
\hline Service efficiency & 0.631 & \\
\hline Factor 2: Variety and value & & 0.614 \\
\hline Menu variety & & 0.591 \\
\hline $\begin{array}{l}\text { Pricing options (from less } \\
\text { expensive to more expensive } \\
\text { at restaurant) }\end{array}$ & & \\
\hline Product options & & 0.519 \\
\hline Value for money & & 0.428 \\
\hline $\begin{array}{l}\text { Pricing (differently priced } \\
\text { restaurants) }\end{array}$ & & 0.414 \\
\hline Eigenvalue & $\mathbf{1 . 1 3 0}$ & $\mathbf{2 . 9 5 1}$ \\
\hline $\begin{array}{l}\text { Cronbach's } \boldsymbol{\alpha} \text { reliability } \\
\text { coefficient }\end{array}$ & $\mathbf{0 . 7 0 1}$ & $\mathbf{0 . 6 9 3}$ \\
\hline Inter-item correlations & $\mathbf{0 . 5 4 0}$ & $\mathbf{0 . 3 2 9}$ \\
\hline $\begin{array}{l}\text { Mean value (standard } \\
\text { deviation) }\end{array}$ & $\mathbf{1 . 3 8 ( \pm . 5 3 )}$ & $\mathbf{2 . 1 9}( \pm .62)$ \\
\hline
\end{tabular}

\section{Retail experience factors}

Table 3 reveals a similar principal axis factor analysis for the 11 retail constructs, resulting in three factors that had eigenvalues greater than 1.0. These factors accounted for $50 \%$ of the variance and were labelled Goods and services, Pricing and Quality. The reliability alphas for the three factors were above 0.45 . Factor 1 , Goods and services, constituted the focus on fastmoving consumer goods, products aimed at a variety of markets, separate curio sales and discounts for Wild Card holders (a park loyalty card giving discounts on conservation area fees). The second factor, Pricing, included the points that shops were too expensive and a 
preference for using park shops as opposed to exiting the park and using those outside. The third factor, Quality, comprised purchasing provisions outside of parks as part of the holiday experience, that retail brands would enhance the experience so that no major product purchase changes were required, and that shops had to focus on freshness of products. The mean value for Pricing was slightly higher than Goods and services and Quality, which indicates that pricing was more important to park visitors. Factor scores were calculated as the average of all items contributing to a specific factor in order to interpret them on the original fivepoint Likert scale of measurement where $5=$ totally disagree; $4=$ disagree; $3=$ neutral; $2=$ agree and $1=$ totally agree. Based on the mean values, respondents indicated that they agreed more with the Goods and services factor at the shops compared to Quality aspects (3.30). The two aspects in Pricing (Factor 2), namely "shops are too expensive" and "I would rather pay more at park shops than exit the park while on holiday"), were treated as separate items due to their low Cronbach alpha value. The Cronbach alpha values for Goods and services and Quality were both above 0.5, which is acceptable. However, the Cronbach alpha for Pricing was 0.45 , which is not reliable and was thus reported separately. The mean for "shops are too expensive" was 2.21 , while that for "I would rather pay more at park shops than exit while on holiday" was 2.45 , indicating that respondents agreed or strongly agreed with these two constructs even though they contradict each other. Therefore, respondents complain about the high prices but they would rather pay more than be obliged to leave the park to buy goods. For discussion purposes, these two constructs were respectively labelled Expensive shops and Pay more inside Park. The factor, Quality, shows two constructs that were reversed in order to form part of the factor analysis. These aspects were "shops should focus on freshness of products" and "retail brands would enhance my experience".
Table 3: Results of the factor analysis for retail experience

\begin{tabular}{|c|c|c|c|}
\hline \multirow[t]{2}{*}{ Retail experience factors } & \multicolumn{3}{|c|}{ Factor loadings } \\
\hline & 1 & 2 & 3 \\
\hline \multicolumn{4}{|l|}{$\begin{array}{l}\text { Factor 1: Goods and } \\
\text { services }\end{array}$} \\
\hline $\begin{array}{l}\text { Shops to focus on basic } \\
\text { necessities }\end{array}$ & 0.654 & & \\
\hline $\begin{array}{l}\text { Shops should aim at a } \\
\text { variety of markets }\end{array}$ & 0.635 & & \\
\hline $\begin{array}{l}\text { Curios should be sold } \\
\text { separately }\end{array}$ & 0.607 & & \\
\hline $\begin{array}{l}\text { Wild Card holders should } \\
\text { get discounts }\end{array}$ & 0.591 & & \\
\hline \multicolumn{4}{|l|}{ Factor 2: Pricing } \\
\hline $\begin{array}{l}\text { Rather pay more at shops } \\
\text { in park than exit during } \\
\text { holiday }\end{array}$ & & 0.879 & \\
\hline Shops are too expensive & & 0.656 & \\
\hline \multicolumn{4}{|l|}{ Factor 3: Quality } \\
\hline $\begin{array}{l}\text { Buying provisions before } \\
\text { leaving for holiday is part } \\
\text { of the holiday experience }\end{array}$ & & & 0.864 \\
\hline $\begin{array}{l}\text { Retail brands would } \\
\text { enhance retail experience }\end{array}$ & & & 0.599 \\
\hline $\begin{array}{l}\text { The park shops do not } \\
\text { require major changes }\end{array}$ & & & 0.521 \\
\hline $\begin{array}{l}\text { Shops should focus on } \\
\text { freshness of goods }\end{array}$ & & & 0.434 \\
\hline Eigenvalue & 2.799 & 1.189 & 1.035 \\
\hline $\begin{array}{l}\text { Cronbach's } \alpha \text { reliability } \\
\text { coefficient }\end{array}$ & 0.551 & 0.457 & 0.576 \\
\hline Inter-item correlations & 0.235 & 0.304 & 0.264 \\
\hline $\begin{array}{l}\text { Mean value (standard } \\
\text { deviation) }\end{array}$ & $\begin{array}{r}2.48 \\
( \pm .63) \\
\end{array}$ & - & $\begin{array}{r}3.30 \\
( \pm .72) \\
\end{array}$ \\
\hline
\end{tabular}

Results of the relationships between dining and retail factors

Spearman's rank order correlations have been used to describe the strength and direction of the linear relationship between two variables, namely, to determine the relationship between dining and retail factors with one another. ANOVAs were used to explore the effect of the use of park restaurants on retail and dining factors.

\section{Spearman correlations between retail and dining factors}

Table 4 indicates the correlations between the retail factors: Goods and services, Quality, Expensive shops and Pay more inside Park and the dining factors: Quality, Variety and value and Nature ambience (purpose 2 as stated in the introduction). 
Table 4: Spearman's rank order correlations for retail and dining experience factors

\begin{tabular}{l|c|c|c|c|c|c|c}
\hline & $\begin{array}{c}\text { Goods and } \\
\text { services }\end{array}$ & $\begin{array}{c}\text { Quality } \\
\text { (retail) }\end{array}$ & $\begin{array}{c}\text { Variety and } \\
\text { value }\end{array}$ & $\begin{array}{c}\text { Quality } \\
\text { (dining) }\end{array}$ & $\begin{array}{c}\text { Nature } \\
\text { ambience }\end{array}$ & $\begin{array}{c}\text { Pay more } \\
\text { inside Park }\end{array}$ & $\begin{array}{c}\text { Expensive } \\
\text { shops }\end{array}$ \\
\hline Goods and services & 1.000 & $\mathbf{- . 4 1 0 ^ { * * }}$ & $\mathbf{. 3 7 1 * *}$ & $.255^{* *}$ & $.059^{* *}$ & $-.114^{* *}$ & $.345^{* *}$ \\
\hline Quality (retail) & $\mathbf{- . 4 1 0 ^ { * * }}$ & 1.000 & $-.293^{* *}$ & $-.215^{* *}$ & $-.080^{* *}$ & $.106^{* *}$ & $-.284^{* *}$ \\
\hline Variety and value & $\mathbf{. 3 7 1 * *}$ & $-.293^{* *}$ & 1.000 & $.336^{* *}$ & $.189^{* *}$ & $-.143^{* *}$ & $.297^{* *}$ \\
\hline Quality (dining) & $.255^{* *}$ & $-.215^{* *}$ & $.336^{* *}$ & 1.000 & $.186^{* *}$ & -.025 & $.198^{* *}$ \\
\hline Nature ambience & $.059^{* *}$ & $-.080^{* *}$ & $.189^{* *}$ & $.186^{* *}$ & 1.000 & $.043^{* *}$ & $.055^{* *}$ \\
\hline Pay more inside park & $-.114^{* *}$ & $.106^{* *}$ & $-.143^{* *}$ & -.025 & $.043^{* *}$ & 1.000 & $-.294^{* *}$ \\
\hline Expensive shops & $\mathbf{. 3 4 5 ^ { * * }}$ & $-.284^{* *}$ & $.297^{* *}$ & $.198^{* *}$ & $.055^{* *}$ & $-.294^{* *}$ & 1.000 \\
\hline$* *$
\end{tabular}

** Correlation is significant at 0.01 level (two-tailed)

* Correlation is significant at 0.05 level (two-tailed)

Based on the results portrayed in Table 4, it is clear that there is a strong correlation between the retail and dining factors. The most significant negative correlation is between Quality (retail) and Goods and service (-.410). This indicates that when one variable increases, the other decreases, and an inverse relationship exists between the two variables. Therefore, an increase in Quality (retail) aspects such as "buying provisions before leaving on holiday" and "retail brands would enhance my experience" would mean that Goods and services such as "shops should have products aimed at a variety of markets" and "shops should focus on fast-moving goods" would no longer be a necessity and would decrease. The most significant positive correlations are between Variety and value and Goods and services (.371) and Expensive shops and Goods and services (.345). A positive relationship indicates that an increase in one variable results in an increase in the other, and vice versa. An increase in Variety and value aspects such as "product options" and "pricing options" would increase Goods and services such as "products aimed at a variety of markets" and "shop should focus on fast-moving goods". When the factor Expensive shops increases, there is an increase in Goods and services such as "Wild Card holders should receive discounts".

\section{ANOVA for comparisons by restaurant use}

Each of the factors listed in Table 5 produced statistically significant differences in the park shop/restaurant use category (purpose 3 as stated in the introduction). For respondents who never made use of shops/restaurants and takeaways, Quality (dining), Variety and value and Nature ambience were more important than for other respondents. These respondents also agreed with the factor Shop inside Park which indicates that they would prefer to make use of park shops for convenience. Respondents who only used takeaway facilities and not restaurants disagreed with Goods and services such as "shops should focus on fast-moving goods" and "shops should offer products to a variety of markets". These aspects were not considered important, as respondents did not make use of the shop to purchase products, but only for takeaways. Respondents who used restaurants on more than one occasion and those who only made use of takeaway facilities agreed with Quality (retail). Aspects such as "retail brands would enhance my retail experience" and "shops should focus on fast-moving goods" would affect these respondents more, as they were the ones who made use of the facilities and, as such, would benefit.

Table 5: ANOVA for comparison of restaurants and shop factors by restaurant use

\begin{tabular}{|c|c|c|c|c|c|c|}
\hline $\begin{array}{l}\text { Dining and retail } \\
\text { factors }\end{array}$ & $\begin{array}{c}\text { Not at all } \\
N=740\end{array}$ & $\begin{array}{c}\text { At least once } \\
\mathbf{N}=2389\end{array}$ & $\begin{array}{c}\text { More than one } \\
\text { occasion } \\
\mathrm{N}=1831\end{array}$ & $\begin{array}{c}\text { Only use } \\
\text { takeaway, not } \\
\text { restaurant } \\
\mathrm{N}=497\end{array}$ & F-value & p-value \\
\hline Dining factors & $\begin{array}{l}\text { Mean and } \\
\text { standard } \\
\text { deviation }\end{array}$ & $\begin{array}{l}\text { Mean and } \\
\text { standard } \\
\text { deviation }\end{array}$ & $\begin{array}{c}\text { Mean and } \\
\text { standard } \\
\text { deviation }\end{array}$ & $\begin{array}{c}\text { Mean and } \\
\text { standard } \\
\text { deviation }\end{array}$ & & \\
\hline Quality & $1.49( \pm .73)$ & $1.37( \pm .50)$ & $1.35(.48)$ & $1.33( \pm .48)$ & 12.495 & $.000^{*}$ \\
\hline Variety and value & $2.30( \pm .75)$ & $2.20( \pm .60)$ & $2.16( \pm .57)$ & $2.11( \pm .59)$ & 14.275 & $.000 *$ \\
\hline Nature ambience & $2.01( \pm 1.12)$ & $1.81( \pm .92)$ & $1.73( \pm .90)$ & $1.82( \pm .95)$ & 14.911 & $.000 *$ \\
\hline Retail factors & $\begin{array}{l}\text { Mean and } \\
\text { standard } \\
\text { deviation }\end{array}$ & $\begin{array}{c}\text { Mean and } \\
\text { standard } \\
\text { deviation }\end{array}$ & $\begin{array}{c}\text { Mean and } \\
\text { standard } \\
\text { deviation }\end{array}$ & $\begin{array}{l}\text { Mean and } \\
\text { standard } \\
\text { deviation }\end{array}$ & & \\
\hline Goods and services & $2.48( \pm .65)$ & $2.48( \pm .62)$ & $2.49( \pm .63)$ & $2.37( \pm .59)$ & 5.220 & $.001 *$ \\
\hline Quality & $3.26( \pm .79)$ & $3.28( \pm .71)$ & $3.34( \pm .69)$ & $3.33( \pm .71)$ & 3.359 & $.018^{*}$ \\
\hline Shop inside park & $2.76( \pm 1.22)$ & $2.44( \pm 1.13)$ & $2.30( \pm 1.13)$ & $2.59( \pm 1.22)$ & 30.744 & $.000^{*}$ \\
\hline Expensive shops & $1.96( \pm .92)$ & $2.22( \pm .88)$ & $2.36( \pm .95)$ & $2.01( \pm .89)$ & 42.156 & $.000 *$ \\
\hline
\end{tabular}

\footnotetext{
* Indicates statistically significant differences $\mathrm{p}=<0.05$
} 


\section{Findings and implications}

The purpose of this research was threefold, as indicated earlier: firstly, to determine the factors that influence visitors' retail and dining experiences in South African national parks; secondly, to determine whether there is a relationship between these experiences and thirdly to determine whether the use of park restaurants/shops influence such experiences. Based on the results, this research has the following findings and implications:

The first finding gives answers to the first objective mentioned above, where three dining experience factors were identified, namely Quality, Variety and value and Nature ambiance. Quality was regarded as the most important factor, indicating satisfaction with park restaurants is more important than variety and value of offerings as well as the experience of nature while dining in national parks. This supports Yüksel and Yüksel's (2002), Sparks et al.'s (2003), Correia et al.'s (2008) and Chang et al.'s (2011) findings that quality (of services and products) and diversity significantly influence the dining experience. This finding exerts a direct influence on standards, service delivery, staff training, menu options and the variety of affordable meals. The importance of Quality furthermore supports the introduction of SANParks' Commercialisation Strategy (SANParks, 2011). The introduction of franchised restaurants and shops as suggested by Gäl et al. (2007) may also be a way to ensure consistent quality of services and goods. Interestingly, Nature ambience was regarded as a less important factor for a memorable dining experience at national parks, which contradicts the findings by most researchers as discussed in the literature review (Correia et al., 2008; Gül et al., 2007; Ryu \& Jang, 2007; Sparks et al., 2008) who found that atmosphere greatly influences dining experiences. This is an intriguing result in the case of a national park, where the dining facilities are regarded as secondary to the wildlife and nature experience. Another possible explanation for the low scoring of Nature ambience could be that national parks already provide a nature and wildlife setting or ambience. Results still highlight that even though visitors go to such parks to relax and experience nature, they nevertheless expect and want superior levels of quality experiences at dining facilities. Therefore, park management needs to ensure quality service and products, even if these are provided by means of franchises.

In terms of the retail experience, interesting results identified four factors: Goods and services, Pricing (consisting of two separate constructs: Expensive shops and Pay more inside Park) and Quality. However, respondents rated Pricing of items as more important than the Goods and services and Quality factors. This confirms the research by Maubach et al. (2009) and Mak et al. (2012) which postulated that price is one of the factors that affect food and retail preferences. Thus, visitors to national parks indicate that pricing is the most important aspect when it comes to retail, which implies respondents want affordable goods. However, while respondents feel that the park shops are too expensive, if they had a choice, they would rather pay more for supplies inside the parks than purchase cheaper goods outside the parks during their stays. This indicates that better or more competitive pricing is required in park shops. Currently, these shops have a monopoly since SANParks do not offer visitors any alternatives and they are able to make large mark-ups on their products. However, more competitive prices will lead to more purchases (a greater volume of sales) and consequently, a higher income for national parks, which is what SANParks wants to achieve. Franchised shops may also be an option in this regard, as they mostly charge standardised prices. Further, respondents agreed more with the Goods and services at the park shops compared to Quality aspects. This implies that park shops should focus on not only providing a greater variety, but also the more basic necessities, such as fresh milk and bread, especially during high season when shops run out of stock. They should aim at offering products for a variety of markets including, for example, options for Halaal and Kosher products, as well as low-calorie products for health conscious visitors. In addition, respondents want a variety of affordable curios sold in a separate, clearly marked area inside the shops that offer benefits such as discounts for Wild Card holders.

The second objective set out to determine the relationship between park visitors' retail and dining experiences. Results showed a strong correlation between the retail and dining factors while the most significant negative correlation was between Quality (retail) and Goods and service. This implies that park management should address respondents' dining and retail requirements simultaneously, since they use both. This may be done by ensuring three aspects: (1) good quality, (2) greater variety and (3) well priced goods and services. Ensuring these would mean that more respondents are likely to use the restaurants and shops more often, and to spend more inside the park.

The third finding addresses the third objective of the study: whether the use of park restaurants and shops influences visitors' retail and dining experiences. Results of the ANOVA confirm a strong relationship, which from a management point of view supports the implication stated under the second finding: that respondents' dining preferences and retail preferences and experiences should not be managed and addressed separately.

\section{Conclusion}

In light of the challenge faced by SANParks with regard to declining government funding as well as the negative influence on visitor spending of the poor service levels in shops, restaurants and eating facilities, SANParks need to improve the retail and dining experiences at these facilities. This research attempted to provide guidelines to park management in addressing these issues by determining visitors' retail and dining preferences and the relationship between these constructs. Three dining experience factors were identified: Quality, Variety and value and Nature ambience and four retail experience factors: Goods and services, Pricing (consisting of two separate constructs: 
Expensive shops and Pay more inside Park) and Quality. This was the first time, to the best of the authors' knowledge, that research addressing visitors' retail and dining preferences has been conducted at any national park in South Africa, thereby contributing significantly to literature regarding visitor experiences in a nature-based context. The results could also be useful to other national parks and even privately owned game farms that experience similar problems. Results emphasised that in order to create memorable dining and retail experiences, park managers should concurrently manage these two constructs as they significantly influence each other. Implementing this management strategy should ensure the quality, affordability and variety of products and meals offered in park shops and restaurants, which will result in higher visitor spending inside the Parks. This in turn will lead to greater income being generated. A possible solution park management might consider in order to achieve the latter is the introduction of franchised shops and restaurants. However, visitors' perceptions regarding this and the potential influence thereof on the park atmosphere necessitate further research. It is further recommended that this type of research is expanded upon and conducted at each separate national park, as opposed to a national survey. This will provide the managers of each individual park with direct and customised guidelines on how to enhance visitors' retail and dining experiences.

\section{References}

Ab Karim, S. \& Geng-Qing Chi, C. 2010. 'Culinary tourism as a destination attraction: An empirical examination of destinations' food image', Journal of Hospitality Marketing and Management, 19:531-555

Boniface, P. 2003. Tasting tourism: travelling for food and drink. Burlington, VT: Ashgate.

Bowie, D. \& Buttle, F. 2011. Hospitality marketing principles and practice. $2^{\text {nd }}$ ed. Oxford: Butterworth-Heinemann.

Boyne, S., Williams, F. \& Hall, D. 2002. The Isle of Arran taste trail. In Hjalager, A.M. and Richards, G. (Ed.). Tourism and gastronomy. London, England: Routledge. Pp.91-114.

Brady, M.K. \& Robertson, C.J. 2001. 'Searching for a consensus on the antecedent role of service quality and satisfaction: an exploratory cross-national study', Journal of Business Research, 51:53-60.

Brumback, N. 1999. 'Roamin' holiday', Restaurant Business, 98(2).

Chang, R.C.Y., Kivela, J. \& Mak, A.H.N. 2010. 'Food preferences of Chinese tourists', Annals of Tourism Research, 37(4):989-1011.

Chang, R.C.Y., Kivela, J. \& Mak, A.H.N. 2011. 'Attributes that influence the evaluation of travel dining experiences: When East meets West', Tourism Management, 32(2011):307-316.

Child, B. 2009. Conservation in transition. In Suich, H., Child, B. \& Spencley, A., (Ed). Evolution and innovation in wildlife conservation. Oxfordshire: Earthscan. pp. 3-15.
Clark, G. \& Chabrel, M. 2007. 'Measuring integrated rural tourism', Tourism Geographies, 9:371-386.

Clark, L.A. \& Watson, D. 1995. 'Constructing validity: Basic issues in objective scale development', Psychological Assessment, 7(3):309-319.

Cohen, J. 1988. Statistical power analysis for the behavioral sciences. 2nd ed. Hillsdale, NJ: Erlbaum.

Correia, A., Moital, M., Ferreira da Costa, C. \& Peres, R. 2008. 'The determinants of gastronomic tourists' satisfaction: A secondorder factor analysis', Journal of Foodservice, 19:164-176.

Eagles, P.F.J. 2007. Global trends affecting tourism in protected areas. In Bushell, R. \& Eagles, P.F.J., (Ed.). Tourism and protected areas benefits beyond boundaries. Oxfordshire: CAB International. pp. 27-43.

Eagles, P.F.J., McCool, S.F. \& Haynes, C.D. 2002. Financial aspects of tourism in protected areas. In Phillips, A., (Ed.). Sustainable tourism in protected areas: guidelines for planning and management. Gland, Switzerland: IUCN, pp. 119-144.

Emerton, L., Bishop, J. \& Thomas, L. 2006. Sustainable financing of protected areas: a global review of challenges and options. Geneva, Switzerland: The World Conservation Union (IUCN). .

Gäl, A., Akbay, C., Özcicek, C., Özel, R. \& Ozdes Akbay, A. 2008. 'Expenditure pattern for food away from home consumption in Turkey', Journal of International Food \& Agribusiness Marketing, 19(4):31-43.

Hall, C.M. \& Mitchell, R. 2001. Wine and food tourism. In Douglas, N. and Derrett, R. (Ed.). Special interest tourism. Brisbane: John Wiley and Sons.

Hall, C.M. \& Sharples, L. 2003. The consumption of experiences or the experiences of consumption? An introduction to the tourism of taste. In Hall, C.M., Sharples, E., Mitchell, R., Macionis, N. and Cambourne, B. (Ed.). Food tourism around the world: development, management and markets. Oxford: Butterworth Heinemann. pp.1-24.

Hartman, K.B., Meyer, T. \& Scribner, L.L. 2009. 'Retail and service encounters: The inter-cultural tourist experience', Journal of Hospitality Marketing and Management, 18:197-215.

Henderson, J.C. 2009. 'Food tourism reviewed', British Food Journal, 111(4):317-326.

Hjalanger, A.M. \& Corigliano, M.A. 2000. 'Food for tourists: Determinants of an image'. International Journal of Tourism Research, 2(4):281-293.

Hurst, J.L., Niehm, L.S. \& Littrell, M.A. 2009. 'Retail service dynamics in a rural tourism community. Implications for customer relationship management', Managing Service Quality, 19(5):511540.

Ilbery, B., Kneafsey, M., Bowler, I. \& Clark, G. 2003. Quality products and services in the lagging rural regions of the European Union: a producer perspective. In Beesley, K., Millward, H., Ilbery, B. and Harrington, L. (Ed.). The new countryside: geographic perspectives on rural change. Manitoba, Canada: Brandon University. 
Kim, Y.G., Eves, A. \& Scarles, C. 2009. 'Building a model of local food consumption on trips and holidays: a grounded theory approach', International Journal of Hospitality Management, 28:423-431

Kivela, J.J. \& Crotts, J.C. 2006. 'Tourism and gastronomy: Gastronomy's influence on how tourists experience a destination', Journal of Hospitality and Tourism Research, 30(3):354-377.

Kivela, J.J. \& Crotts, J.C. 2009. 'Understanding travelers' experiences of gastronomy through etymology and narration', Journal of Hospitality and Tourism Research, 3(2):161-192.

Kruger, M., Scholtz, M. \& Saayman, M. 2012. Executive summary of research profiles of selected National Parks in South Africa over 10 years. Potchefstroom: Tourism Research in Economic Environs and Society.

Kumar, P. 2010. Marketing of hospitality and tourism services. New Delhi: Tata McGraw-Hill Publishers.

Lloyd, A.E., Yip, L.S.C. \& Luk, S.T.K. 2011. 'An examination of the differences in retail service evaluation between domestic and tourist shoppers in Hong Kong', Tourism management, 32:520533.

Long, L. 2002. Culinary tourism. Lexington, KY: The University Press of Kentucky.

Mabunda, M.D. 2004. Historical overview of tourism development in the KNP. In Mabunda, M.D. An integrated tourism management framework for the Kruger National Park, South Africa. Pretoria: University of Pretoria. (Thesis - PhD). p. 72-115.

Mabunda, M.D \& Wilson, D. 2009. Commercialisation of National Parks: South Africa's Kruger National Park as an example. In Saarinen, J., Becker, F., Manwa, H. \& Wilson, D. (Ed.). Sustainable tourism in Southern Africa. Bristol, UK: Channel View Publications.

Mak, A.H.N., Lumbers, M. \& Eves, A. 2012. 'Globalisation and food consumption in tourism', Annals of Tourism Research, 39(1):171-196.

Meyer, M.K. \& Conklin, M.T. 1998. 'Variables affecting high school students' perceptions of school foodservice', Journal of the American Dietetic Association, 98:1424-1431.

Neild, K., Kozak, M. \& LeGrys, G. 2000. 'The role of food service in tourist satisfaction', International journal of hospitality management, 19(2):375-384.

O’Hara, P.A., Harper, D.W., Kangas, M., Dubeau, J., Borsutzky, C. \& Lemire, N. 1997. 'Taste, temperature and presentation predict satisfaction with foodservices in a Canadian continuing-care hospital', Journal of the American Dietetic Association, 97:404405 .

Pallant, J. 2010. SPSS Survival manual: A step-by-step guide to data analysis using SPSS version 16. $4^{\text {rd }}$ ed. New York: McGrawHill.

Rogerson, C.M. 2011. 'Urban tourism and regional tourists: Shopping in Johannesburg, South Africa', Tijdschrift Voor Economische en Sociale Geografie, 102(3):316-330.
Ryu, K. \& Han, H. 2011. 'New and repeat customers: How does physical environment influence their restaurant experience?', International Journal of Hospitality Management, 30:599-611.

Ryu, K. \& Jang, S. 2007. 'The effect of environmental perceptions on behavioural intentions through emotions: The case of upscale restaurants', Journal of Hospitality and Tourism Research, 31(1):56-72.

Saayman, M. \& Saayman, A., 2008. 'Estimating the economic contribution of visitor spending in the Kruger National Park to the regional economy', Journal of Sustainable Tourism, 14(1):67-81.

Saayman, M. \& Scholtz, M. 2012. Visitors' perception of the nonconsumptive value of selected species and game viewing in South African National Parks. Potchefstroom: TREES, NWU:.

Saporiti, N. 2006. Managing national parks: how public-private partnerships can aid conservation. Washington, DC: World Bank Group.

Sims, R. 2009. 'Food, place and authenticity: local food and sustainable tourism experience', Journal of Sustainable Tourism, 17(3):321-336

South African National Parks. 2011a. About SANParks: brief history. [Online] http://www.sanparks.org/ about/history.php

South African National Parks. 2011b. South African National Parks: annual report 2010/2011. [Online] http://www.sanparks.org/assets/docs/general/annual-report2011.pdf

South African National Parks. 2012a. South African National Parks: annual report 2011/2012. [Online] http://www.sanparks.org/assets/docs/general/annual-report2012.pdf

South African National Parks. 2012b. South African National Parks: annual performance plan for 2012/13. [Online] http://www.sanparks.org/assets/docs/about/ annual_performance_plan_2012-2013.pdf

South African National Parks. 2012c. South African National Parks: Strategic plan for the fiscal 2012/13-2016/17. [Online\} http://www.sanparks.org/assets/docs/ about/5_year_strategic_plan_2012-2013_to_2016-2017.pdf

South African National Parks. 2012d. Wild card programme membership. [Online] http://www.sanparks.org/wild_new/

Sparks, B., Bowen, J. \& Klag, S. 2003. 'Restaurants and the tourist market', International Journal of Contemporary Hospitality, 15(1):6-13

Sparks, B.A., Wildman, K. \& Bowen, J. 2000. 'Restaurants as a contributor to tourist destination attractiveness: Phase one - expert interviews', CRC for Sustainable tourism working paper.

Steyn, H.S. 2000. 'Practical significance of the difference in means', South African Journal of Industrial Psychology, 26(3):1-3.

$\mathrm{Su}, \mathrm{C} .2011$. 'The role of service innovation and customer experience in ethnic restaurants', The Service Industries Journal, 31(3):425-440. 
Telfer, D. \& Wall, G. 1996. 'Linkages between tourism and food production', Annals of Tourism Research, 23(3):635-653.

Torres, R. 2002. 'Towards a better understanding of tourism and agriculture linkages in the Yucatan: Tourist food consumption and preferences', Tourism Geographies, 4:282-307.

Tsai, C. \& Lu, P. 2012. 'Authentic dining experiences in ethnic theme restaurants', International Journal of Hospitality Management, 31:304-306.

Tse, P. \& Crotts, J.C. 2005. 'Antecedents of novelty seeking: International visitors' propensity to experiment across Hong Kong's culinary traditions', Tourism Management, 26:965-968.

Van Westering, J. 1999. Gastronomy and tourism. In Molloy, J. and Davies, J. (Ed.). Proceedings of the $9^{\text {th }}$ Australian Tourism and Hospitality Research Conference, Council for Australian University Tourism and Hospitality Education - Part Two, Bureau of Tourism Research, Canberra, p. 63.

Varghese, G. 2008. Public-private partnerships in South African national parks: the rationale, benefits and lessons learnt. In Spenceley, A., (Ed.). Responsible tourism. London: Earthscan. pp. 69-83.

Weiss, R., Feinstein, A. \& Dalbor, M. 2004. 'Customer satisfaction of theme restaurant attributes and their influence on return intent', Journal of Foodservice Business Research, 7:23-41.

Woodland, M. \& Acott, T. 2007. 'Sustainability of local tourism branding in England's South Downs', Journal of Sustainable Tourism, 15:715-734.

Wray, M. n.d. Sanparks puts Kruger's restaurants into liquidation.[Online] http://www.krugerpark.co.za/ krugerparktimes-2-17-krugers-restaurants-20700.html

Wyman, M., Barborak, J.R., Inamdar, N. \& Stein, T. 2011. 'Best practices for tourism concessions in protected areas: A review of the field', Forests, 2(4):913-925.

Yüksel, A. \& Yüksel, F. 2002. 'Measurement of tourist satisfaction with restaurant services: A segment-based approach', Journal of Vacation Marketing, 9(1):52-68. 